\title{
Medios audiovisuales y músicas populares: Comunicación, representación y diversidad en la esfera mediática
}

\section{Fran Ayuso - Josep Pedro}

Este dossier aborda las relaciones entre los medios audiovisuales y las músicas populares desde una perspectiva comunicativa. Ante la multiplicidad y complejidad de textos, caminos y sinergias, el objetivo es analizar la producción de sentido y las estrategias e interacciones comunicativas a partir de distintos casos de estudio, que nos remiten a diversas situaciones y contextos. En ellos se abordan una importante variedad de cuestiones en torno a las interacciones entre imagen y música, la historia de los medios de comunicación y de los géneros musicales, y las implicaciones políticas, identitarias, raciales y de género de la producción audiovisual, tanto en el siglo XX como en el XXI.

A modo de introducción cabe señalar que, en consonancia con la tradición de la semiótica y los estudios literarios y culturales, indagamos en la relación entre medios audiovisuales y músicas populares en relación a aspectos textuales y pragmáticos. Así, asumimos una noción amplia del texto (escrito, visual, verbovisual, musical...), e incidimos también en los contextos, situaciones y efectos generados en el ámbito de la comunicación. La música constituye un lenguaje compartido por todo tipo de sociedades, capaz de vencer prejuicios, saltar barreras culturales y conectar emocionalmente con todo tipo de públicos. De la misma forma, es capaz de generar todo tipo de odios.

Como práctica cultural generalizada, la música es capaz de generar espacios sensibles y vasos comunicantes en los que se construyen identidades, se refuerzan prácticas sociales, se desbordan emociones, se perfilan formas de reconocimiento social y se articulan redes transculturales. Efectivamente, estos procesos tienen un resultado material y simbólico en las prácticas cotidianas de las personas. De ahí que suponga un medio extraordinario para reflexionar acerca de cómo se articulan los procesos y las transformaciones sociales: cómo se construyen miedos y pesadillas, cómo se potencian sentimientos y anhelos; de qué manera se perfilan nuevos paisajes, insólitas aventuras; desde qué supuestos se refuerzan viejas doctrinas o se transforman las tradiciones; con qué paradójica fecundidad contribuye la globalización a los procesos de hibridación.

La música y las imágenes, así como las interconexiones que se producen entre las mismas, no solo constituyen instrumentos esenciales para comprender el mundo en que vivimos y el lugar que en él ocupamos, dentro de una determinada línea de tiempo; sino también representaciones culturales que condicionan las formas de ver, escuchar y entender las distintas realidades que nos conforman. La relación que se establece entre un elemento de la banda sonora y un elemento de la banda imagen genera una articulación que permite producir distintos sentidos, matices y ambigüedades.

Desde la etapa del cine silente, cuando un pianista acompañaba rítmica y melódicamente a las imágenes en movimiento, la música y el cine han mantenido una fructífera relación, que fluye en ambos sentidos y altera la percepción tanto de las imágenes como de los sonidos y músicas. Al entrar en contacto con las imágenes, la música puede reforzar o anticipar una determinada 
emoción, también rememorar un sentimiento pasado; es capaz de adentrarnos en el clima sonoro de un género concreto o de situarnos en un lugar y un tiempo reconocibles. Asimismo, puede actuar como elemento definitorio de un personaje o como instrumento dinamizador de la acción y, de manera asincrónica, puede abrirnos espacios de significación más allá de las imágenes a las que acompaña. Con el paso del tiempo, se han ido instaurando y asimilando ciertas pautas sonoras que, al ser reconocidas, remiten a unas coordenadas simbólicas y referenciales relativamente precisas.

Aunque, en virtud de su índole artística y poética, la música no se deja conducir hacia un resultado objetivo; conjuga ritmo, melodía y armonía con interacción comunicativa, llamada y respuesta e improvisación. De igual manera, el montaje de imágenes tiene una función poética, por la capacidad que tienen las mismas de variar su sentido y posición simbólica al entrar en contacto unas con otras. «Más allá de la operación puramente técnica», señala Abril (2003: 126), el montaje implica «un principio de organización cognitiva y textual» que supone siempre dos fases: «una analítica en la que el sujeto de la enunciación desmembra unidades o significantes y una sintética, de reconstrucción y resemantización».

Ya Charles Chaplin advertía que el cine guarda una mayor relación con la música que con cualquier otro arte. A sus apreciaciones podemos añadir las de Vázquez Montalbán (2000: XII), quien plantea la interesante sugerencia de que «la canción es un medio de comunicación prácticamente audiovisual, puesto que rara vez una canción se desliga de su intérprete» -y de las imágenes que acompañan a la música o son suscitadas por ella, cabría añadir. Este camino nos lleva a considerar la importancia central de los imaginarios visuales que se forman en torno a las músicas populares. Incluyen imágenes de cantantes, músicos, discos, videoclips, cine, series, publicidad, videojuegos, etc., y en esos espacios se construyen y reconstruyen tanto las propias músicas como como las narrativas y ficciones que, impregnadas de músicas, mutan en su naturaleza y sentido.

Se vuelve necesario repensar todas estas cuestiones en un momento en que el audiovisual se ha convertido en un magma multiforme que ha terminado devorando a medios tradicionales como el cine. ${ }^{1}$ Este universo audiovisual nos provee de un torrente de imágenes y sonidos por medio de diferentes pantallas de uso diario (para más sobre la pantalla contemporánea, véase Márquez, 2015). En este fecundo paisaje abundan las rupturas o la permeabilidad de las antiguas fronteras, y las influencias y las relaciones dialógicas circulan en múltiples direcciones. Al mismo tiempo, los contenidos se tornan vulnerables a operaciones de apropiación y reelaboración, y su conocimiento se ha vuelto cada vez más fragmentario por la influencia de redes masivas como YouTube o Instagram. Es en este terreno en permanente transformación donde surgen propuestas como Clímax (Gaspar Noé, 2018), que mediante una puesta en escena que potencia lo coreográfico y lo corporal sobre lo narrativo acaba fundiéndose con los videoclips del dj Kiddy Smile, que hace de sí mismo en el film. Tampoco tiene reparo en convocar a esta rave lisérgica a Cioran, Murnau, Bataille, Pasolini o Fassbinder. Otro ejemplo sería la forma en que el colorido que caracteriza la ropa y los bailes de cierta cultura africana, en sintonía con los ritmos hip hop, se convierte en un adorno prêt-à-porter en el videoclip Made For Now de Janet Jackson y Daddy Yankee, o en una reivindicación de las raíces africanas en la obra de la rapera de origen zambiano Sampa The Great, cuya composición y videoclips Final Form emplea la afirmación «iBlack Power.» como grito de guerra. Otro caso destacable es el videoclip This is America, de Childish Gambino, que desde la forma del plano secuencia construye una serie de imágenes potentes e impactantes que se dispersan en una multiplicidad de referentes y casos reales ocurridos en EE. UU., y que lo convierten en un complejo artefacto audiovisual de denuncia y reflexión.

Los artículos de este dossier nos aproximan a distintos medios, objetos y perspectivas, a múltiples lugares y tiempos históricos. Tres de ellos están vinculados a

En el libro que Ángel Quintana dedica al cine en la era digital advierte que «el cine considerado como un medio de expresión surgido de la mecanización de la sociedad del siglo XIX se ha convertido en una pieza más de una serie de procesos característicos del siglo XXI en los que la informatización de la cultura ha acabado generando nuevas formas de ver y de poseer el mundo» (2011: 37). 
la televisión, si bien en distinta forma: Begoña Gutiérrez Martínez analiza el papel de la música en Mad Men, una serie de televisión contemporánea ambientada en la década de 1960; Pedro Cravinho investiga la actuación televisada de Josephine Baker en Lisboa en el año 1960, durante la dictadura Estado Novo (1933-1974); y María García Celdrán y Enrique Encabo reflexionan en torno a las audiencias juveniles y la educación musical tomando como casos de estudio Operación Triunfo y La Voz: Otros dos artículos están dedicados al cine musical: María Aparisi se centra la representación de la identidad afroamericana y la negritud en el cine musical de Hollywood de las décadas de 1930 y 1940 , y Teresa Fraile en el cine musical español de la década de 1960, inmerso en el tardofranquismo y la apertura internacional. Además, Marcelo Jaume indaga en la complicada relación entre el jazz y el videoclip contemporáneo, y Michael Arnold examina la economía cultural y la representación aurática en la escena indie a través del caso de Pony Bravo.

El análisis de Gutiérrez Martínez revela el modo en que las relaciones establecidas entre la música y las imágenes que dan cuerpo a la serie se desarrollan en varios niveles de interacción, que contribuyen a la construcción de sentido ya sea por continuidad, contraste o ambivalencia. Estas operaciones posibilitan diferentes lecturas que ahondan en la dualidad que caracteriza tanto al personaje principal como al conjunto de la serie. Resulta muy interesante apreciar el modo en que diferentes elementos de la puesta en escena aportan tonalidades que, al interactuar con los colores sugeridos por la banda musical, enriquecen la experiencia del espectador e inciden en la complejidad de temas como el deseo, el desengaño, el éxito, la frustración o las problemáticas sociales e históricas. Tratándose de una serie ambientada en la década de 1960, resultan de gran interés tanto las elecciones musicales que afirman su precisión histórica como las que introducen anacronismos.

1, 2, 3... al escondite inglés (Zulueta, 1969) constituye un ejemplo de cine contracultural en la España de los años 1960. Una década marcada por el auge del turismo y una voluntad aperturista por parte del régimen, que no mermaba la represión que se vivía en las calles.
Acontecimientos de carácter internacional, como la celebración en 1969 del Festival de Eurovisión en España, eran instrumentalizados institucionalmente como un lavado de cara de la dictadura. Precisamente, la película de Zulueta se centra en la celebración de un festival similar para criticar «la visión unívoca de España ofrecida hacia el extranjero por los medios de comunicación gubernamentales» y plasmar las tensiones que se vivían en el plano social. Esta visión crítica se articula en la música, valorando las influencias del pop, rock, soul y funk frente a la música melódica que dominaba el panorama nacional; $\mathrm{y}$ a nivel formal, por la experimentación visual en la composición de videoclips de influencia psicodélica y de arte pop. La relevancia de la televisión ocupa un lugar de autorreflexión en el filme, pues suponía una oportunidad para experimentar con nuevos formatos y corrientes musicales en programas como El último grito.

Aparisi Galán elabora una análisis crítico de un cortometraje y un filme interpretados por la cantante de jazz Billie Holiday para identificar los estereotipos raciales y de género y situarlos en el marco de las dinámicas de rechazo y deseo identificables en la construcción de la negritud en el cine de la primera mitad del silgo XX. Estas prácticas de construcción de identidades dicotómicamente racializadas, que normaliza la superioridad de la identidad «racial» blanca, se insertan en la tradición colonial, en las que la animalización e infantilización del subalterno sirve como punto de contraste para conformar la identidad blanca acomodada. En los ejemplos expuestos se analizan prácticas como la del blackface, recurso fetichista de identificación y rechazo de la negritud.

En el marco de la investigación histórica sobre el jazz en Portugal, Cravinho examina las implicaciones políticas de la actuación de Josephine Baker en 1960. Contextualiza la dictadura portuguesa (Estado Novo), explora las múltiples caras de Baker — bailarina, cantante, espía y activista-, y analiza la retransmisión y la interpretación musical a partir de trabajo bibliográfico y de archivo. Marcada por la elección de Terra Seca, una canción de Ary Barroso vinculada a la experiencia de las personas negras, la interpretación televisada de Josephine Baker en la Radio y Televisión de Portugal (RTP) 
se revela como una forma de oposición a las políticas coloniales portuguesas, en consonancia con el compromiso político adquirido por la artista afroamericana. De forma paradójica y subversiva, la aclamada Josefina Baker fue capaz de celebrar su negritud y de cuestionar el colonialismo portugués en la propia televisión pública de un régimen de extrema derecha, que la empleaba como aparato ideológico sujeto a la censura.

El artículo de Jaume ahonda en la relación ambivalente del jazz con la noción de «música popular»y el videoclip contemporáneo. Pese a su vínculo histórico con el cine y su protagonismo en el audiovisual de otras épocas, el jazz no tiene un espacio de representación habitual en el videoclip contemporáneo, hecho que invita al autor a examinar los posibles motivos de esta relación conflictiva. El texto discute numerosos ejemplos en relación a sus modos de relato. Reflexiona sobre la condición instrumental e improvisatoria del jazz y aborda la relación del jazz con el pop y con el hip hop, señalando que, frente a la actitud conservadora del jazz más influido por el pop, el contacto e hibridación con la música rap tienden a generar una mayor experimentación en el audiovisual.

García Celdrán y Encabo contextualizan la relación preeminente de los jóvenes con las tecnologías de la información y la comunicación. Influyen en el modo de pensarse a sí mismos y en el lugar que ocupan en un mundo que es a un tiempo local, global y deslocalizado. Hablemos de «millennials» o de «nativos digitales», se dan ciertas características relacionadas con la sobreinformación, la pantallización, la interconexión, la cultura visual y la interactividad, que condicionan poderosamente la relación que mantienen con el entorno. La educación musical es uno de los ámbitos que se ve alterado por este ecosistema tecnológico. El estudio de formatos televisivos de gran audiencia, como La Voz y Operación Triunfo, permite indagar en sus mensajes y valores respecto a la educación musical. Conceptos como éxito y fracaso, esfuerzo y disfrute, o compañerismo e individualismo son puestos en juego en espectáculos televisivos similares al reality, dependientes de los índices de audiencia y asociados a toda una serie de productos de consumo.
El análisis de Arnold sobre el grupo sevillano Pony Bravo en tanto representante de la escena musical indie indaga en el original estilo musical y visual del grupo, que conecta con una variedad de tradiciones tanto globales como locales, generalmente representativas del sur geográfico y cultural. El autor explora la inflación del capital subcultural en torno a la música indie - resultado de la aproximación y el solapamiento de lo indie con lo mainstream - así como las estrategias empleadas por distintos participantes para afirmar y proclamar su identidad y pertenencia a la escena. En este proceso, aplica con solvencia y originalidad los conceptos de economía cultural y de aura, llevando algunos de los planteamientos de Walter Benjamin al mundo del indie y la industria musical actual.

\section{Agradecimientos}

Este artículo, así como la edición del dossier dedicado a la relación entre medios audiovisuales y músicas populares, se enmarca en dos proyectos de investigación financiados en los que han participado de manera independiente los autores: «Interculturalidad, Biopolítica y Tecnologías de género», financiando por la Generalitat Valenciana, referencia: AICO/2017/123; y «Problemas públicos y controversias: diversidad y participación en la esfera mediática», financiado por el Ministerio de Ciencia, Innovación y Universidades, referencia: CSO201782109-R (MICINN).

\section{Bibliografía}

ABRIL, Gonzalo (2003), Cortar y pegar: la fragmentación visual en los orígenes del texto informativo, Madrid: Cátedra.

Quintana, Ángel (2011), Después del cine. Imagen y realidad en la era digital. Barcelona: Acantilado.

MÁrQUEZ, Israel V. (2015), Una genealogía de la pantalla: del cine al teléfono móvil. Barcelona: Anagrama.

VÁzquez Montalbán, Manuel (2000), Cancionero General del Franquismo 1939-1975. Barcelona: Crítica. 